\title{
PENERAPAN METODE PEMBELAJARAN KOOPERATIF TIPE EXAMPLES NON EXAMPLES UNTUK MENINGKATKAN HASIL BELAJAR KOGNITIF SISWA
}

\author{
Ferdinant Alexander \\ Dosen STAKN KUPANG \\ nand.soinbala@gmail.com \\ Fenni Regina Pono \\ Mahasiswa STAKN KUPANG \\ fennypono17@gmail.com
}

\begin{abstract}
The application of cooperative learning methods types of examples non examples in classroom action research is intended to build students' imagination and critical thinking skills in learning. It is hoped that learning outcomes in the cognitive domain will increase. This research was conducted in two cycles. The subjects of this study were students in 5th grade of SD Inpres Oesapa Kecil 1 Kota Kupang totaling 23 students and consisted of 15 male students and 8 female students. Data collection tecniques used was observation, tests, and performance. The data analysis technique used is quantitative and qualitative data analysis. The results of the research showed a significant increase in the average percentage of classical completeness. The researcher concluded that the application of the learning methods succeeded in improving learning outcomes of Christian Religious Education subjects for 5 th grade students of SD Inpres Oesapa Kecil 1 Kota Kupang.
\end{abstract}

Keywords: cooperative learning methods type examples non examples, cognitive learning outcomes

\begin{abstract}
Abstrak
Penerapan metode pembelajaran kooperatif tipe examples non examples dalam penelitian tindakan kelas kali ini dimaksudkan untuk membangun imajinasi dan kemampuan berpikir kritis siswa dalam belajar dengan harapan hasil belajar pada ranah kognitif akan meningkat. Penelitian ini dilakukan dalam dua siklus kepada siswa kelas V SD Inpres Oesapa Kecil 1 Kota Kupang yang berjumlah 23 siswa terdiri dari laki-laki 15 siswa dan perempuan 8 siswa. Teknik Pengumpulan data menggunakan observasi, tes, dan unjuk kerja. Teknik analisis data yang digunakan yaitu analisis data kuantitatif dan kualitatif. Hasil penelitian pada siklus pertama dan kedua menunjukkan peningkatan yang berarti pada nilai rata-rata persentasi ketuntasan klasikal. Peneliti menyimpulkan bahwa penerapan metode pembelajaran kooperatif tipe examples non examples berhasil meningkatkan hasil belajar kognitif Pendidikan Agama Kristen siswa kelas Vc SD Inpres Oesapa Kecil 1 Kota Kupang.
\end{abstract}

Kata Kunci: metode pembelajaran kooperatif tipe examples non examples, hasil belajar kognitif 


\section{Pendahuluan}

Pemilihan metode pembelajaran yang tepat dapat menjadi trigger meningkatnya hasil belajar. Hal ini dimungkinkan karena pada prinsipnya metode pembelajaran dapat berfungsi dalam tiga hal, yaitu sebagai motivator ekstrinsik, sebagai strategi pembelajaran, dan sebagai alat untuk mencapai tujuan. ${ }^{1}$ Memilih dan menetapkan metode pembelajaran sama artinya dengan memilih dan menetapkan tujuan pembelajaran, sebab metode memiliki signifikansi fungsional yang kuat dan terarah dengan tujuan pembelajaran. Oleh karena itu, pemilihan metode sebagai strategi dalam pembelajaran haruslah didasari oleh pertimbangan bahwa metode tersebut dapat digunakan sebagai pendorong efektif bagi terciptanya interaksi edukatif yang dapat menumbuhkan kegiatan berpikir aktif dan mandiri bagi siswa, ${ }^{2}$ sebagai dasar dari upaya pencapaian hasil belajar yang maksimal.

Belajar pada hakekatnya melibatkan aktivitas berpikir, sebab berpikir adalah aktivitas spontan insan yang berakal. Meskipun berpikir merupakan sebuah reaksi akali yang bersifat spontan, proses ini seyogianya ditunaikan dengan penuh kesadaran sehingga memberikan kemungkinan bagi perkembangan kemampuan berpikir asosiatif, analitis, kritis, dan kreatif.

Dalam ilmu psikologi, proses berpikir disebut juga proses kognisi. Neisser menyebutnya sebagai kegiatan organisme (manusia) untuk mengetahui, memperoleh, mengorganisasikan dan menggunakan pengetahuan. ${ }^{3}$ Secara cermat proses ini melibatkan kegiatan mental seperti menimbang, mengamati, mengingat, menganalisis, mensintesis, mengevaluasi, mengkreasi dan memecahakan persoalan yang berlangsung melalui interaksi dengan lingkungan. Kompleksitas ini memungkinkan kemampuan kognitif menjadi fondasi yang kokoh sekaligus stimulus munculnya kecakapan individu dalam pengambilan keputusan sekaligus menjadi penuntun yang mengarahkan tingkah laku.

Tolak ukur pengamatan kemampuan kognitif dapat didasarkan pada hierarki taksonomi Bloom (yang kemudian direvisi oleh Anderson dan Krathwohl) yang mengurutkan ranah kognitif pada 6 tingkatan, yaitu: mengingat (remember), memahami (understand), menerapkan (apply), menganalisis (analyze), menilai/mengevaluasi (evaluate), dan menciptakan (create). ${ }^{4}$ Ranah $\mathrm{C} 1$ (mengingat) menjadi level terendah dari kemampuan kognitif, sedang ranah C6 (menciptakan) menjadi level tertinggi dari kemampuan kognitif. 2010), 72.

${ }^{1}$ Syaiful Bahri Djamarah and Aswan Zain, Strategi Belajar Mengajar (Jakarta: Rineka Cipta,

2 Leryani Mince Maria Manuain, Ferdinant Alexander, and Marsi Bombongan Rantesalu, "Pengaruh Model Pembelajaran Jigsaw Terhadap Peningkatan Hasil Belajar Sejarah Pendidikan Agama Kristen," Ciencias: Jurnal Penelitian dan Pengembangan Pendidikan 1, no. 1 (2018): 1-12, accessed November 11, 2019, https://ejournal.upg45ntt.ac.id/ciencias/article/view/9.

3 Puspo Nugroho, "Pandangan Kognitifisme Dan Aplikasinya Dalam Pembelajaran Pendidikan Agama Islam Anak Usia Dini," Jurnal ThufulLA: Jurnal Inovasi Pendidikan Guru Raudhatul Athfal 3, no. 2 (2015): 290.

${ }^{4}$ Imam Gunawan and Anggarini Retno Palupi, “Taksonomi Bloom - Revisi Ranah Kognitif: Kerangka Landasan untuk Pembelajaran, Pengajaran, dan Penilaian," Journal Premiere Educandum: Pendidikan Dasar dan Pembelajaran 2, no. 2 (2012): 105; Penjelasan tiap dimensinya adalah sebagai berikut: 1) mengingat berarti mengambil pengetahuan tertentu dari memori jangka panjang, 2) memahami berarti mengkonstruksi makna dari materi pembelajaran, termasuk apa yang diucapkan, ditulis dan digambar oleh guru, 3) mengaplikasikan berarti menerapkan atau menggunakan suatu prosedur dalam keadaan tertentu, 4) menganalisis berarti memecah-mecah materi jadi bagian-bagian penyusunnya dan menentukan hubungan antar bagian itu dan hubungan antar bagian-bagian tersebut dan keseluruhan struktur atau tujuan, 5) mengevaluasi berarti mengambil keputusan berdasarkan kriteria dan/atau standar, dan 6) mencipta berarti memadukan bagian-bagian untuk membentuk sesuatu yang baru dan koheren atau untuk membuat suatu produk yang orisinal; Lorin 
Penelitian yang dilakukan oleh Bujuri mengemukakan bahwa perkembangan kognitif siswa pada Usia 11 tahun (kelas V SD) telah berpindah dari fase operasional konkrit yang membutuhkan kehadiran objek nyata sebagai acuan berpikirnya ke fase operasional formal, yang bersifat abstrak, idealis dan logis. Pada fase ini, siswa sudah dapat menggunakan pemikiran hipotesis-deduktif yakni kemampuan mengembangkan hipotesa atau prediksi terbaik, serta mampu berpikir sistematis dalam menyusun langkah-langkah strategis demi menyelesaikan suatu permasalahan. Dengan mengacu pada hierarki Bloom, maka pada tahap ini, siswa sedang belajar mengembangkan keterampilan berpikir tingkat tinggi (Higher orders Thingking Skills) yaitu pada dimensi proses kognitif menganalisis (C4), mengevaluasi/menilai (C5) dan menciptakan (C6). ${ }^{5}$

Dalam rangka memenuhi kebutuhan pengembangan kemampuan berpikir siswa, maka model siklus belajar hipotesis deduktif adalah model yang paling baik digunakan dalam rangka mengembangkan daya kritis siswa yang pada gilirannya berpengaruh terhadap peningkatan pemahaman konsep. Bujuri, ketika mengemukakan hasil penelitiannya menyatakan bahwa siswa mampu berpikir secara kritis, ketika dihadapkan dengan masalah. Siswa akan memahami sebab-akibat terlebih dahulu, baru kemudian menyusun langkah untuk menyelesaikannya. Daya ingat siswa semakin kuat dan sudah dapat berpikir strategis serta menyusun siasat. Pada fase ini model pembelajaran yang terpusat pada siswa (student center) sudah dapat diterapkan, baik dengan model kooperatif, model inkuiri, maupun dengan model pembelajaran konstruktivisme. ${ }^{6}$

Slavin menjelaskan bahwa pembelajaran kooperatif merupakan pembelajaran yang mengajak siswa bekerja sama dalam kelompok untuk menguasai materi yang disampaikan guru. ${ }^{7}$ Model Pembelajaran Kooperatif adalah kegiatan pembelajaran dengan cara berkelompok untuk bekerja sama saling membantu mengkonstruksi konsep, menyelesaikan persoalan atau inkuiri. ${ }^{8}$

Ragam model pembelajaran kooperatif sangat bervariasi. Salah satu di antaranya adalah tipe examples non examples. Pemilihan metode pembelajaran ini dilandasi oleh presuposisi bahwa sebagai salah satu pendekatan group investigation, pembelajaran tipe ini dirancang untuk mempengaruhi pola interaksi dan aktivitas siswa dalam membangun konsep dan menyelesaikan persoalan secara bersama-sama. Dalam pelaksanaannya metode

W. Anderson and David R. Krathwohl, eds., Kerangka Landasan Untuk Pembelajaran, Pengajaran, Dan Asesmen (Yogyakarta: Pustaka Pelajar, 2014), 43.

${ }^{5}$ Dian Andesta Bujuri, “Analisis Perkembangan Kognitif Anak Usia Dasar dan Implikasinya dalam Kegiatan Belajar Mengajar," LITERASI IX, no. 1 (2018): 48; bnd. John W. Santrock, Perkembangan Anak (Jakarta: Erlangga, 2007), 257-258. Keterampilan bepikir tingkat tinggi yang diterjemahkan dari Higher Order Thinking Skills (HOTS) adalah kegiatan berpikir yan \g melibatkan level kognitif hierarki tinggi dari taksonomi Bloom. Dalam perkembangannya kemampuan berpikir remembering, understanding dan applying dikategorikan dalam recalling dan processing, kemampuan berpikir analysing dan evaluating dikategorikan dalam critical thinking, dan kemapuan berpikir creating dikategorikan dalam creative thingking.

${ }^{6}$ Dian Andesta Bujuri, "Analisis Perkembangan ...: 48

7 Aris Shoimin, 68 Model Pembelajaran Inovatif dalam Kurikulum 2013 (Yogyakarta: Ar-Ruzz, 2016), 45

8 Suyatno, Menjelajah Pembelajaran Inovatif (Sidoarjo: Madmedia Buana Pustaka, 2009), 51; Penerapan model pembelajaran ini searah dengan semangat kurikulum 2013 yang menekankan bahwa konsep dasar pembelajaran K-13 mengedepankan pengalaman individu dan diarahkan untuk meningkatkan kreativitas siswa dan aktivitas kolaboratif untuk mencapai aspek kognitif yang meliputi daya kritis, keratif, analitis dan evaluatif. Rinto Hasiholan Hutapea, "Evaluasi Pembelajaran Pendidikan Agama Kristen Pada Kurikulum 2013," Jurnal Ilmiah Religiosity Entity Humanity (JIREH) 1, no. 1 (2019): 25 
ini menggunakan contoh-contoh berupa gambar atau peragaan suatu prosedur yang harus dilakukan peserta didik. ${ }^{9}$

Gambar merupakan salah satu alat yang jika digunakan dalam proses belajar mengajar dapat membantu dan melatih diri siswa mengembangkan pola pikirnya. Gambar juga mempunyai peranan penting dalam proses belajar mengajar, yakni untuk mempermudah dan membantu siswa dalam membangkitkan imajinasinya dalam belajar. Selain itu dengan mengggunakan gambar, siswa dapat melatih mencari dan memilih urutan yang logis sesuai dengan materi yang diajarkan. Penggunaan metode pembelajaran examples non examples ini lebih menekankan pada kemampuan analisis siswa. Umumnya, metode ini lebih dominan digunakan di kelas tinggi, namun dapat juga digunakan di kelas rendah dengan menekankan aspek psikologis dan tingkat perkembangan siswa kelas rendah seperti: kemampuan berbahasa tulis dan lisan, kemampuan analisis ringan, dan kemampuan berinteraksi dengan siswa lainnya. ${ }^{10}$

Adapun langkah-langkah pelaksanaan metode pembelajaran example non example adalah sebagai berikut: 1) guru mempersiapkan gambar-gambar sesuai dengan tujuan pembelajaran; 2) guru menempelkan gambar di papan atau ditayangkan melalui media proyeksi; 3) guru membentuk kelompok yang dapat terdiri dari 2-3 orang siswa; 4) guru memberi petunjuk dan memberi kesempatan pada siswa untuk memperhatikan dan menganalisis gambar bersama-sama dalam diskusi kelompok; 5) siswa mencatat pada kertas konsep yang telah dikonstruksi dari hasil analisis gambar; 6) tiap kelompok diberi kesempatan mempresentasikan hasil diskusinya; 7) guru mulai menjelaskan materi sesuai tujuan yang ingin dicapai dengan memperhatikan hasil analisis gambar yang telah dilakukan kelompok; 8) guru dan siswa menyimpulkan materi sesuai dengan tujuan pembelajaran. ${ }^{11}$

Penelitian tindakan kelas dengan melakukan penerapan metode pembelajaran examples non examples telah banyak dilakukan dan menunjukkan hasil yang memuaskan jika diamati dari peningkatan hasil belajarnya. Beberapa diantaranya dapat dikemukakan yaitu penelitian yang dilakukan oleh Putri Suyanti, dkk dengan judul Penerapan Model Pembelajaran Examples Non Examples Pada Materi Tokoh-Tokoh Sejarah untuk Meningkatan Hasil Belajar Siswa Kelas V SDN Gunungsari menunjukkan tingkat keberhasilan 90\% siswa yang mencapai Kriteria Ketuntasan Minimal (KKM) dari 55\% sebelum metode ini diterapkan. Artinya terdapat peningkatan 35\% pada hasil belajar siswa. ${ }^{12}$ Demikian juga penelitian yang dilakukan oleh Syarifah Habibah, dengan judul Penggunaan Model Pembelajaran Examples Non Examples Terhadap Ketuntasan Hasil Belajar Siswa Pada Materi Tokoh-Tokoh Pergerakan Nasional Kelas V SDN 70 Banda Aceh. Nilai rata-rata meningkat pada angka 77.75 dengan tingkat keberhasilan $90 \%$ siswa yang mencapai KKM. ${ }^{13}$

Penerapan metode pembelajaran kooperatif tipe examples non examples kali ini berbeda, sebab dilakukan pada mata pelajaran Pendidikan Agama Kristen (PAK) sebagai

${ }^{9}$ Fendi Lestiawan and Arif Bintoro Johan, "Penerapan Metode Pembelajaran Example NonExample Untuk Meningkatkan Keaktifan Dan Hasil Belajar Dasar-Dasar Pemesinan," Jurnal Taman Vokasi 6, no. 1 (2018): 99

10 Syarifah Habibah, "Penggunaan Model Pembelajaran Examples Non Examples Terhadap Ketuntasan Hasil Belajar Siswa Pada Materi Tokoh-Tokoh Pergerakan Nasional Kelas V SDN 70 Banda Aceh," Jurnal Pesona Dasar 3, no. 4 (2016): 57

11 Miftahul Huda, Model-Model Pengajaran Dan Pembelajaran (Yogyakarta: Pustaka Pelajar, 2013), 235

12 Putri Suyanti, Nurdinah Hanifah, and Dede Tatang Sunarya, "Penerapan Model Pembelajaran Examples Non Examples Pada Materi Tokok-Tokoh Sejarah Untuk Meningkatkan Hasil Belajar Siswa Kelas V SDN Gunungsari," Jurnal Pena Ilmiah 2, no. 1 (2017): 2051-2060.

${ }^{13}$ Syarifah Habibah, “Penggunaan Model...: 54-64 
upaya peningkatan hasil belajar siswa pada dimensi proses kognitif menganalisis (C4), yang meliputi keterampilan membedakan, mengorganisasi dan mengatribusi. Kemampuan yang diukur pada tahap ini adalah kemampuan siswa dalam membedakan fakta dari pendapat, mengidentifikasi unsur-unsur pada pokok permasalahan dan membangun hubungan yang sistematis dan koheren dari potongan-potongan informasi yang diberikan. Untuk mencapai maksud di atas, maka instrumen tes disusun dengan mengacu pada kegiatan evaluasi perkembangan keterampilan tersebut.

Penelitian ini didasarkan atas beberapa permasalahan belajar siswa, di antaranya: 1) perhatian siswa terhadap proses pembelajaran sangat rendah; dan 2) pembelajaran dengan menggunakan metode ceramah masih mendominasi, sehingga siswa tidak diberi kesempatan untuk mengembangkan diri sesuai dengan perkembangan kognitifnya, di mana siswa seharusnya telah memiliki kemampuan menkonstruksi konsep dan menyelesaikan masalah yang diberikan. Permasalahan-permasalahan di atas berdampak kepada aktivitas proses pembelajaran yang tidak menyenangkan serta hasil belajar siswa yang terlihat buruk. Data statistik menunjukkan bahwa jumlah siswa yang mencapai KKM berada di bawah angka $31 \%$.

Tabel 1. Distribusi dan Presentase Hasil Belajar pada Ranah Kognitif Siswa Kelas V SD Inpres Oesapa Kecil 1 Kota Kupang pada Pra Tes/ Pra Siklus Berdasarkan KKM

\begin{tabular}{|c|c|c|c|}
\hline Kriteria KKM & Kategori & Jumlah Siswa & Persentase (\%) \\
\hline $75-100$ & Tuntas & 7 & $30,43 \%$ \\
\hline $0-74$ & Tidak Tuntas & 16 & $69,57 \%$ \\
\hline
\end{tabular}

Sumber: olah data nilai tengah semester

Rendahnya jumlah siswa yang mengalami ketuntasan belajar menunjukkan bahwa pengusaan materi oleh siswa belum maksimal. Tingkat pemahaman siswa yang diharapkan mencapai ranah kognitif (C4-C6) belum terpenuhi. Kondisi ini menuntut adanya perbaikan. Permasalahan metode dan media ajar yang dapat merangsang minat menjadi pokok utama yang harus dipecahkan. Penerapan metode pembelajaran kooperatif tipe examples non examples dengan menyajikan gambar-gambar yang melaluinya siswa dapat membangun konsep dan mengembangkan kemampuan analisis dapat dijadikan solusi hingga adanya perbaikan hasil belajar PAK siswa kelas V SD Inpres Oesapa Kecil 1 Kota Kupang.

\section{Metode Penelitian}

Metode yang digunakan dalam penelitian ini adalah Penelitian Tindakan Kelas (Classroom action research). Penelitian Tindakan Kelas (PTK) adalah salah satu jenis penelitian yang berupaya memecahkan masalah-masalah yang dihadapi guru yang berkaitan dengan proses pembelajaran di kelasnya sendiri. ${ }^{14}$ Dalam kajian ini, PTK dilakukan dengan menekankan pada penentuan tindakan-tindakan yang tepat dalam rangka memecahkan dan memperbaiki permasalahan belajar pada ranah kognitif yang ada di dalam kelas, sekaligus memperbaiki dan penyempurnaan kinerja dan praktik mengajar guru dalam proses pembelajaran.

PTK memiliki berbagai macam karakteristik, di antaranya: 1) masalah dalam PTK muncul dari kesadaran diri guru sendiri bukan orang lain. Kesadaran terhadap adanya hal yang mendesak untuk diperbaiki dalam pembelajaran sehari-hari di kelas; 2) mengumpulkan data dari praktek sendiri melalui refleksi diri (self reflective inquiry); 3)

14 Tatang Yuli Eko Siswono, Mengajar Dan Meneliti (Panduan Penelitian Tindakan Kelas Untuk Guru Dan Calon Guru) (Surabaya: Unesa University Press, 2008), 5 
dilakukan di kelas dan fokusnya pada kegiatan pembelajaran yang berupa interaksi guru dan peserta didik; 4) perbaikan dilakukan secara bertahap dan terus-menerus selama kegiatan penelitian, sehingga terdapat siklus yang sistematis. ${ }^{15}$

Penelitian ini dilaksanakan secara berkolaborasi, di mana peneliti berkerjasama dengan guru sebagai kolaborator dalam mengajar mata pelajaran Pendidikan Agama Kristen (PAK). Tindakan yang direncanakan dalam penelitian ini berupa penerapan metode pembelajaran example non example untuk meningkatkan hasil belajar PAK pada ranah kognitif siswa kelas V SD Inpres Oesapa Kecil 1 Kota Kupang.

Prosedur penelitian tindakan dilakukan dalam siklus yang sistematis. Secara garis besar, tiap siklusnya akan melalui empat tahapan sebagaimana yang dikemukan oleh Kemmis dan Tagart, sebagaimana diuraikan oleh Madya ${ }^{16}$, berikut:

1. Perencanaan

Merupakan kegiatan merancang secara rinci tentang apa dan bagaimana tindakan yang akan dilakukan. Rancangan tersebut mencakup penentuan pokok bahasan, menyiapkan rancangan pelaksanan pembelajaran (RPP), merencanakan bahan pembelajaran, media gambar sebagai dasar aktifitas analisis siswa, serta menyiapkan instrumen observasi dan tes untuk menguji aktivitas siswa dan kemampuan kognitif siswa dalam aspek analisis. Di dalam RPP langkah-langkah penerapan metode pembelajaran examples non examples yang ditawarkan dijabarkan secara terperinci.

2. Pelaksanaan

Merupakan pelaksanakan seluruh tindakan yang telah direncanakan secara sistematis dan lengkap.

3. Pengamatan

Merupakan tindakan pengamatan yang dilakukan secara langsung ketika metode pembelajaran examples non examples diterapkan. Pengamatan dilakukan terhadap pelaksanaan langkah-langkah metode pembelajaran examples non examples sekaligus mengamati aktivitas siswa selama kegiatan pembelajaran berlangsung. Hal ini digunakan untuk mengetahui apakah terdapat perubahan yang berarti setelah tindakan dilakukan.

4. Refleksi

Adalah kegiatan evaluasi terhadap pelaksanaan tindakan. Evaluasi dilakukan dengan mengacu kepada data yang telah diperoleh. Hasil evaluasi dijadikan landasan untuk menilai hasil tindakan dan pengambilan keputusan terhadap pelaksanaan siklus selanjutnya.

${ }^{15}$ Ibid., 6

16 Suwarsih Madya, Penelitian Tindakan: Teori Dan Praktik (Bandung: Alfabeta, 2011), 59-66; bnd. Suharsimi Arikunto, Penelitian Tindakan Kelas (Jakarta: Bumi Aksara, 2009), 17-22 
Pelaksanaan tiap siklus mengacu pada gambar berikut:

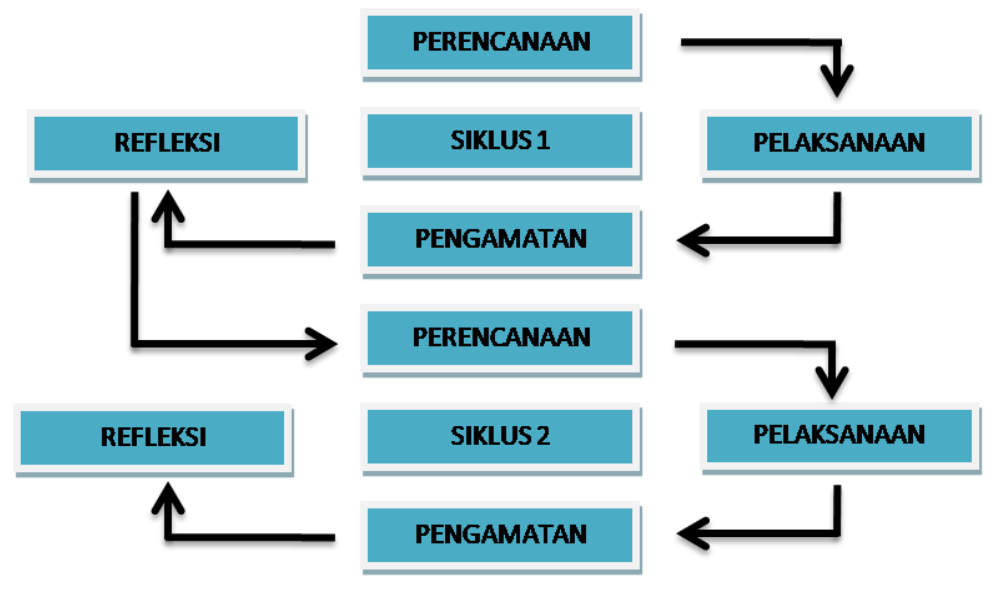

Sumber: Arikunto, 2009:16.

\section{Gambar 1. Siklus PTK}

Subyek dari penelitian tindakan ini adalah siswa kelas Vc SD Inpres Oesapa Kecil 1 Kota Kupang dengan jumlah siswa 23 orang yang terdiri dari 8 orang siswa perempuan dan 15 orang siswa laki-laki. Penentuan subyek ini didasarkan atas permasalahan belajar.

Teknik pengumpulan data dilakukan peneliti melalui observasi dan pemberian tes. Observasi dilakukan dengan berpedoman pada lembar observasi dan dilakukan dengan tujuan mengamati aktifitas siswa ketika menerima pembelajaran dengan penerapan metode pembelajaran examples non examples. Hasil observasi akan dikonversi menjadi skor untuk mengukur besaran keaktifan masing-masing siswa untuk tiap aspek yang diamati. Dengan menggunakan rumus:

$$
\text { Skor }=\frac{\text { Jumlah Skor Tiap Aspek }}{\text { Skor Maksimum Tiap Aspek }} \times 100
$$

Rata-rata skor masing-masing siswa untuk seluruh aspek, dihitung dengan menggunakan rumus:

$$
\text { Rata-rata skor }=\frac{\text { Jumlah skor tiap siswa per aspek }}{\text { Jumlah aspek }} \times 100
$$

Hasil penghitungan ini kemudian dibandingkan dengan tabel kriteria rata-rata keaktifan siswa di bawah ini:

\section{Tabel 3. Kriteria Keaktifan Siswa}

\begin{tabular}{|l|l|}
\hline Rata-rata & Kriteria \\
\hline $81 \%-100 \%$ & Baik sekali (BS) \\
\hline $61 \%-80 \%$ & Baik (B) \\
\hline $41 \%-60 \%$ & Cukup (C) \\
\hline $21 \%-40 \%$ & Kurang (K) \\
\hline$\leq 21 \%$ & Kurang sekali (KS) \\
\hline
\end{tabular}


Sedang, pemberian tes dilakukan untuk mengukur kemampuan kognitif siswa dalam aspek analisis. Tes ini dalam bentuk soal pilihan ganda, isian dan uraian. Tes dilakukan sebelum (pre-test) dan sesudan (post-test) pembelajaran dengan maksud untuk mengetahui hasil belajar siswa sebelum dan sesudah penerapan metode pembelajaran examples non examples.

Analisis data secara deskriptif kuantitatif digunakan untuk mengolah data yang didapat dari hasil tes. Hasil tes ini merupakan hasil belajar pre-test dan post-test. Untuk menghitung hasil tes, baik pre test maupun post test pada proses pembelajaran dengan model kooperatif tipe examples non examples digunakan rumus percentages correction ${ }^{17}$ sebagai berikut:

$$
\mathrm{S}=\frac{R}{N} \times 100 \%
$$

Keterangan:

$S$ : Nilai yang dicari atau yang diharapkan

$\mathrm{R}$ : Jumlah skor dari item atau soal yang dijawab benar

$\mathrm{N}$ : Skor maksimum ideal dari tes yang bersangkutan

100 : Bilangan tetap

Nilai rata-rata siswa dihitung dengan menggunakan rumus: 18

$$
\mathrm{M}=\frac{\sum X}{\sum n}
$$

Keterangan:

$\mathrm{M} \quad=$ Nilai rata-rata siswa (mean)

$\Sigma \mathrm{x} \quad=$ Jumlah nilai siswa

$\mathrm{N} \quad=$ Jumlah siswa

Menghitung persentase ketuntasan dengan menggunakan rumus: ${ }^{19}$

$$
\mathrm{P}=\frac{f}{N} \times 100
$$

Keterangan:

$\mathrm{P} \quad$ = Persentase yang dicari

$\mathrm{f} \quad=$ Jumlah siswa tuntas

$\mathrm{N} \quad=$ Jumlah seluruh siswa

Adapun kriteria ketuntasan atau kelulusan belajar siswa secara keseluruhan dinyatakan sebagai berikut :20

17 Ngalim Purwanto, Prinsip-Prinsip Dan Teknik Evaluasi Pengajaran (Bandung: PT Remaja Rosdakarya, 2012), 112 2011), 109

${ }^{18}$ Nana Sudjana, Penilaian Hasil Proses Belajar Mengajar (Bandung: PT Remaja Rosdakarya,

19 Trianto, Mendesain Model Pembelajaran Inovatif Progresif: Konsep, Landasan Dan Implementasinya Pada KTSP (Jakarta: Kencana, 2010), 241

${ }^{20}$ Nana Sudjana, Penilaian ..., 118 
Tabel 3. Kriteria ketuntasan/kelulusan belajar siswa

\begin{tabular}{|c|c|}
\hline Taraf Penguasaan & Kualifikasi \\
\hline $91-100 \%$ & Sangat Baik \\
\hline $81-90 \%$ & Baik \\
\hline $71-80 \%$ & Cukup \\
\hline $61-70 \%$ & Kurang \\
\hline$<60 \%$ & Gagal \\
\hline
\end{tabular}

Kriteria ketuntasan minimal (KKM) untuk mata pelajaran PAK adalah 70. KKM ini akan digunakan peneliti sebagai barometer keberhasilan belajar peserta didik kelas $\mathrm{V}$ pada mata pelajaran PAK. Artinya, jika hasil tes peserta didik telah mencapai ketuntasan $100 \%$ atau kurang-kurangnya $75 \%$ dari jumlah peserta didik memperoleh nilai 70 , maka pembelajaran dalam penelitian yang dilakukan oleh peneliti dapat dikatakan berhasil. Dalam penerapannya, apabila ketuntasan pada siklus I belum mencapai target yang telah ditentukan maka harus dilaksanakan lagi siklus II dan seterusnya sampai ketuntasan yang diharapkan telah tercapai.

\section{Hasil dan Pembahasan}

Pelaksanaan penelitian tindakan melalui penerapan metode pembelajaran examples non examples dilakukan dalam dua siklus yang sistematis.

Siklus 1

Proses pembelajaran pada siklus 1 dilaksanakan sesuai dengan tahapan-tahapan yang terdapat pada penelitian tindakan kelas, yaitu :

1. Perencanaan

Pada tahap ini, sebelum tindakan penelitian tindakan dilaksanakan, peneliti menyiapkan segala keperluan yang meliputi:

a. Menyiapkan perangkat pembelajaran yang terdiri atas: (1) RPP dan silabus; (2) bahan ajar; (3) media pembelajaran; (4) soal tes (pre-test dan post-test) dan kunci jawaban; (5) lembar observasi.

b. Mempersiapkan fasilitas dan sarana pendukung yang diperlukan di kelas, misalnya alat tulis dan daftar hadir siswa.

2. Pelaksanaan

Pelaksanaan pembelajaran pada siklus 1 dilaksanakan pada hari Kamis, 27 Mei 2019 pada jam pembelajaran PAK dengan alokasi waktu 3X35 menit atau selama 105 menit dengan materi pokok yang di ajarkan tentang pengampunan Allah. Langkahlangkah penerapan metode pembelajaran examples non examples dilakukan sesuai dengan urutan.

Dalam tahap pelaksanaannya, pre-test dan post-test diberikan dan menunjukkan hasil sebagai berikut:

Tabel 4. Pre-test dan Post-test Siklus 1

\begin{tabular}{|c|c|c|c|c|c|}
\hline Hasil Belajar & $\begin{array}{c}\text { Nilai Rata- } \\
\text { rata }\end{array}$ & $\begin{array}{c}\text { Nilai } \\
\text { Terendah }\end{array}$ & Nilai Tertingi & $\begin{array}{c}\text { Jumlah siswa } \\
\text { tuntas }\end{array}$ & $\begin{array}{c}\text { Persentasi } \\
\text { Ketuntasan }\end{array}$ \\
\hline Pre-test & 59.30 & 49 & 75 & 8 & $34,78 \%$ \\
\hline Post-test & 68.26 & 52 & 89 & 15 & $65,21 \%$ \\
\hline \multicolumn{5}{|r|}{} \\
\hline \multicolumn{4}{|r|}{ Sumber: olah data nilai pre-test \& post-test siklus 1 }
\end{tabular}


Data pada tabel menunjukkan fakta bahwa nilai rata-rata pretest Siklus 1 adalah 59.30 dengan nilai terendah 49 , nilai tertinggi 75 , serta persentasi ketuntasan klasikal pretest mencapai $34,78 \%$ dari 23 siswa. Setelah dilaksanakan penerapan tindakan metode pembelajaran examples non examples terjadi peningkatan kemampuan kognitif siswa berupa kenaikan nilai rata-rata menjadi 65,21 , dengan nilai terendah 52 , nilai tertinggi 89 , serta ketuntasan klasikal posttest mencapai $65,21 \%$, atau sebanyak 15 dari 23 siswa yang mengikuti siklus 1 sudah tuntas belajar dengan mendapatkan nilai di atas KKM.

Perbandingan hasil pre-test dan post-test siklus 1 terlihat melalui grafik berikut:

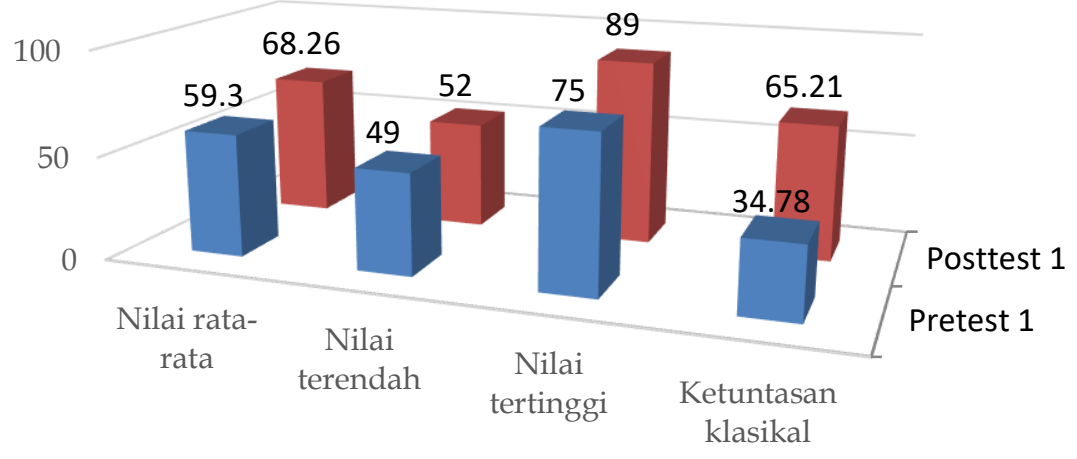

- Pretest 1 Posttest 1

Sumber: olah data nilai pre-test $\mathcal{E}$ post-test siklus 1

\section{Gambar 2. Grafik Pre-test dan Post-test Siklus 1}

3. Pengamatan

Hasil pengamatan terhadap aktifitas siswa selama proses pembelajaran dapat penilit tampilkan dalam dua bagian yaitu pengamatan pra siklus dan pengamatan siklus 1 .

Tabel 5. Perbadingan Predikat Keaktifan Siswa Pra-Siklus dan Siklus 1

\begin{tabular}{|c|c|c|c|c|c|}
\hline Siklus & Aspek yang diamati & $\begin{array}{c}\text { Rata- } \\
\text { Rata } \\
\text { Per } \\
\text { Aspek } \\
(\%)\end{array}$ & $\begin{array}{c}\text { Skor } \\
\text { Terendah } \\
(\%)\end{array}$ & $\begin{array}{c}\text { Skor } \\
\text { Tertinggi } \\
(\%)\end{array}$ & Predikat \\
\hline \multicolumn{6}{|c|}{ Pra-Siklus } \\
\hline & Antusiasme siswa dalam belajar & 47 & 35 & 55 & Cukup \\
\hline & Partisipasi dalam diskusi kelompok & 52 & 40 & 67 & Cukup \\
\hline & Penguasaan Materi & 45 & 30 & 55 & Cukup \\
\hline & Kedisiplinan & 60 & 45 & 75 & Cukup \\
\hline \multicolumn{6}{|l|}{ Siklus 1} \\
\hline & Antusiasme siswa dalam belajar & 64 & 55 & 80 & Baik \\
\hline & Partisipasi dalam diskusi kelompok & 73 & 53 & 80 & Baik \\
\hline & Penguasaan Materi & 64 & 50 & 70 & Baik \\
\hline & Kedisiplinan & 69 & 55 & 80 & Baik \\
\hline
\end{tabular}


Data perbandingan observasi pra-siklus dan siklus 1 menunjukkan bahwa predikat perbandingan keaktifan siswa telah membaik. Akan tetapi jika dilihat dari perbandingan nilai rata-rata per aspek peningkatan yang terjadi belum menunjukkan perubahan yang berarti. Predikat baik yang ditunjukkan pada tabel berasal dari skor 13 orang siswa dengan predikat baik, sedangkan 10 orang siswa masih dengan predikat cukup.

Perbandingan rata-rata keaktifan siswa dappat terlihat secara jelas melalui grafik berikut:

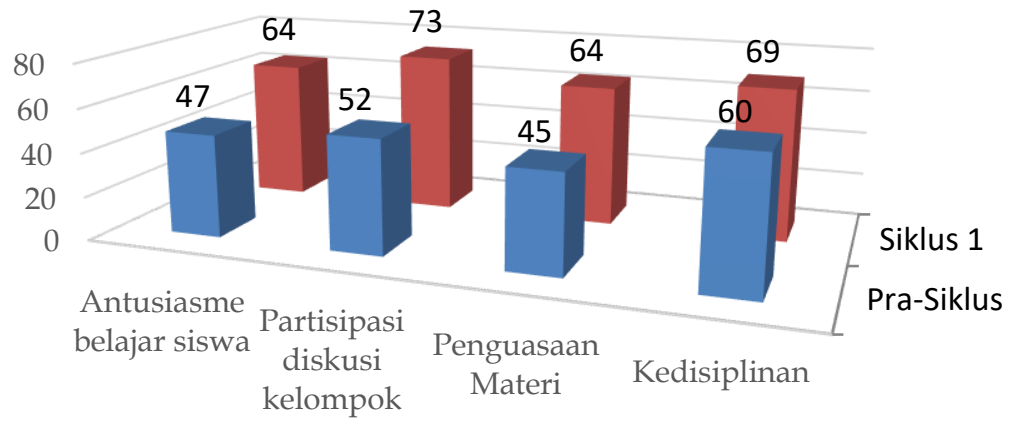

- Pra-Siklus $\quad$ Siklus 1

Sumber: olah data perbandingan rata-rata keaktifan siswa

\section{Gambar 3. Grafik Perbandingan Rata-rata Keaktifan Siswa Pra-Siklus dan Siklus 1}

\section{4. $\quad$ Refleksi}

Dari data-data yang telah dipaparkan di atas dapat dinyatakan bahwa tindakan yang telah diterapkan pada Siklus 1 belum dikatakan berhasil. Oleh karenanya, penelitian ini akan dilanjutkan pada siklus berikutnya dengan mempertimbangkan hal-hal sebagai berikut: 1) merencanakan dan mempersiapkan metode pembelajaran examples non examples dengan lebih baik lagi; 2) memberikan penjelasan mengenai konsep metode pembelajaran examples non examples agar siswa dapat mengikuti pembelajaran dengan optimal; 3) mendorong siswa lebih aktif dalam bertanya, menanggapi pertanyaan yang diberikan dan menjawab pertanyaan dengan benar; 4) mendorong siswa untuk berpikir kritis dalam memahami materi yang disampaikan.

Siklus 2

Proses pembelajaran pada siklus 2 dilaksanakan dengan mempertimbangkan hasil refleksi siklus 1. Langkah-langkah pelaksanaanya tetap mengacu kepada model yang dikemukakan oleh Kemmis dan Tagart, yaitu :

\section{Perencanaan}

Selain kesiapan perangkat pembelajaran sebagaimana yang dikemukakan pada siklus 1, peneliti juga menambahkan satu instrument pengmpulan data yang digunakan untuk memperkuat hasil penelitian yaitu: lembar unjuk kerja diskusi kelompok. Lembar unjuk kerja ini akan melakukan penilaian pada 5 aspek yakni: (1) kerjasama dalam diskusi; (2) kemampuan mengungkapkan pendapat dan mempertahankan pendapat; (3) kemampuan bertanya; (4) keterampilan presentasi, dan (5) hasil tugas. 


\section{Pelaksanaan}

Pelaksanaan pembelajaran pada siklus 2 dilaksanakan pada hari Rabu, 29 Juni 2019 pada jam pembelajaran PAK dengan alokasi waktu 3×35 menit atau selama 105 menit dengan materi pokok yang masih sama dengan yang diajarkan pada siklus 1 yaitu tentang Pengampunan Allah. Langkah-langkah penerapan metode pembelajaran examples non examples dilakukan sesuai dengan urutan dengan memberikan penguatan sebagaimana hasil refleksi siklus 1.

Dalam tahap pelaksanaannya, pre-test dan post-test diberikan dan menunjukkan hasil sebagai berikut:

Tabel 4. Pre-test dan Post-test Siklus 2

\begin{tabular}{|c|c|c|c|c|c|}
\hline Hasil Belajar & $\begin{array}{c}\text { Nilai Rata- } \\
\text { rata }\end{array}$ & $\begin{array}{c}\text { Nilai } \\
\text { Terendah }\end{array}$ & Nilai Tertingi & $\begin{array}{c}\text { Jumlah siswa } \\
\text { tuntas }\end{array}$ & $\begin{array}{c}\text { Persentasi } \\
\text { Ketuntasan }\end{array}$ \\
\hline Pre-test & 71.78 & 58 & 84 & 17 & $73,91 \%$ \\
\hline Post-test & 82.69 & 62 & 99 & 19 & $82,60 \%$ \\
\hline
\end{tabular}

Dari hasil tes belajar yang didapatkan pada siklus 2 maka dapat disimpulkan bahwa peningkatan perkembangan kognitif siswa tentang Pengampunan Allah dengan penerapan metode examples non examples di kelas VC SD Inpres Oesapa Kecil 1 Kota Kupang sudah mencapai tujuan pembelajaran yang diharapakan yaitu memenuhi indikator keberhasilan penelitian dimana $\geq 75 \%$ siswa yang memperoleh nilai $\geq 70$ atau sesuai KKM. Data hasil tes siswa pada siklus 2 ini akan digunakan sebagai bahan refleksi yang dihubungkan dengan data hasil observasi pembelajaran siklus 2. Perbandingan hasil pretest dan posttest siklus 2 dapat dilihat pada grafik sebagai berikut :

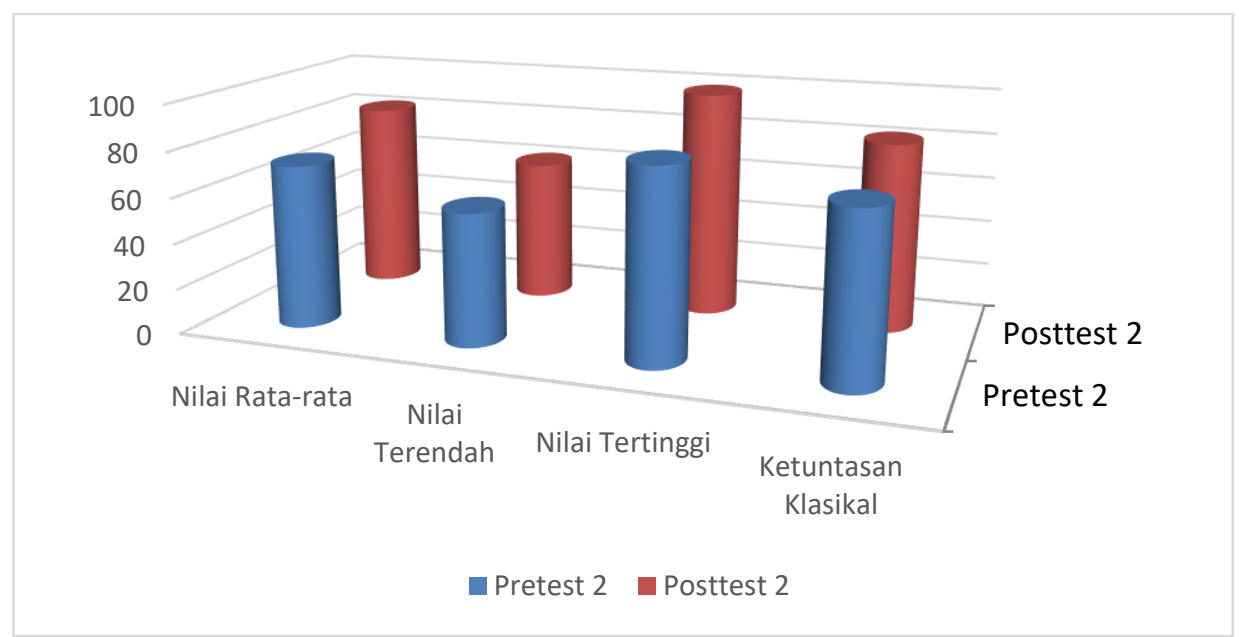

Sumber: olah data nilai pre-test $\mathcal{E}$ post-test siklus 2

\section{Gambar 4. Grafik Pre-test dan Post-test Siklus 2}

\section{Pengamatan}

Hasil pengamatan terhadap aktifitas siswa selama proses pembelajaran pada siklus 2 terlihat melalui tabel berikut. 
Tabel 5. Predikat Keaktifan Siswa Siklus 2

\begin{tabular}{|l|c|c|c|c|}
\hline \multicolumn{1}{|c|}{ Aspek yang diamati } & $\begin{array}{c}\text { Rata-Rata } \\
\text { Per Aspek } \\
\mathbf{( \% )}\end{array}$ & $\begin{array}{c}\text { Skor } \\
\text { Terendah } \\
\mathbf{( \% )}\end{array}$ & $\begin{array}{c}\text { Skor } \\
\text { Tertinggi } \\
\mathbf{( \% )}\end{array}$ & Predikat \\
\hline Antusiasme siswa dalam belajar & 90 & 85 & 100 & Baik Sekali \\
\hline Partisipasi dalam diskusi kelompok & 87 & 73 & 100 & Baik Sekali \\
\hline Penguasaan Materi & 84 & 70 & 100 & Baik Sekali \\
\hline Kedisiplinan & 88 & 80 & 100 & Baik Sekali \\
\hline
\end{tabular}

Data ini menunjukkan adanya peningkatan keaktifan siswa yang sangat berarti. Jika dibandingkan dengan siklus 1, maka aspek antusiasme siswa dalam belajar meningkat $26 \%$ dari posisi awal di angak 64\%; aspek partisipasi dalam sikusi kelompok meningkat $14 \%$ dari posisi awal di angka $73 \%$; aspek pengusaan materi meningkat $20 \%$ dari posisi awal di angka $64 \%$; dan aspek kedisiplinan meningkat $19 \%$ dari posisi awal di angka $69 \%$. Peningkatan yang signifikan ini dapat terlihat melalui grafik berikut:

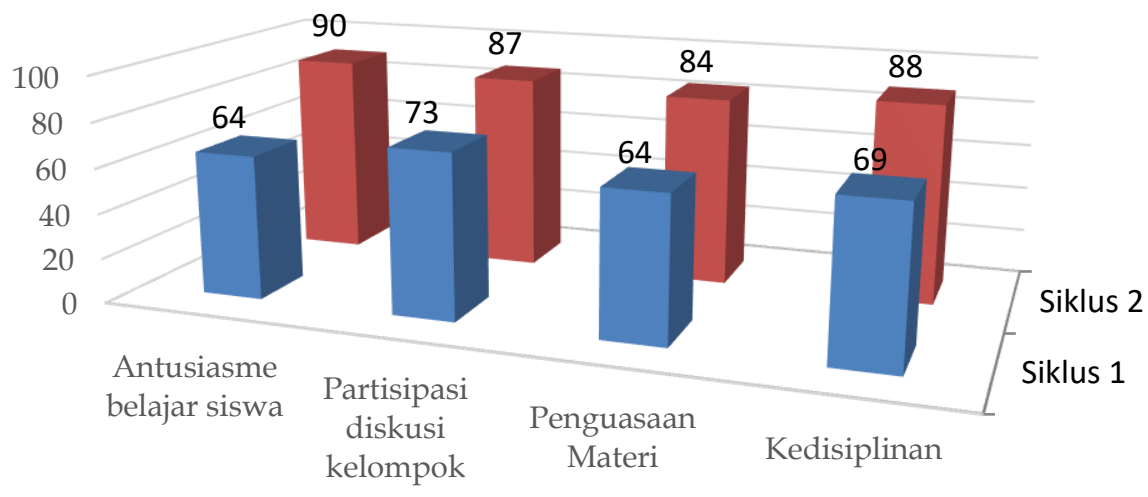

- Siklus 1 Siklus 2

Sumber: olah data perbandingan rata-rata keaktifan siswa

\section{Gambar 5. Grafik Perbandingan Rata-rata Keaktifan Siswa Siklus 1 dan Siklus 2}

Hasil unjuk kerja juga menunjukkan kecenderungan yang sama yaitu bahwa penerapan metode pembelajaran examples non examples berhasil meningkatan keaktifan siswa sekaligus meningkatkan kemampuan kognitif siswa yang tergambar melalui kemampuan mengemukakan pendapat dan mempertahankan pendapat dan kemampuan bertanya yang keduanya merupakan hasil dari kemampuan analisis meningkat. Berikut gambaran lengkap melalui tabel yang disajikan: 
Tabel 6. Kemampuan Siswa dalam Berdiskusi

\begin{tabular}{|l|c|c|}
\hline \multicolumn{1}{|c|}{ Aspek yang dinilai } & $\begin{array}{c}\text { Skor Rata- } \\
\text { rata per } \\
\text { aspek (\%) }\end{array}$ & Predikat \\
\hline Kerjasama dalam berdiskusi dan pembagian tugas & 100 & Baik Sekali \\
\hline Kemampuan mengungkapkan dan mempertahankan pendapat & 80 & Baik \\
\hline Kemampuan bertanya & 80 & Baik \\
\hline Keterampilan Presentasi & 84 & Baik Sekali \\
\hline Hasil tugas & 88 & Baik Sekali \\
\hline
\end{tabular}

6. Refleksi

Dari hasil yang di peroleh pada siklus 2 ini, dapat diketahui bahwa aktifitas siswa maupun hasil belajar meningkat. Berikut rekapitulasi perbandingan data-data penelitian yang menunjukkan peningkatan.

Tabel 7. Perbandingan Pre-test dan Post-test 2 Siklus

\begin{tabular}{|l|c|c|c|c|c|}
\hline \multirow{2}{*}{ Indikator } & \multicolumn{2}{|c|}{ Siklus 1 } & \multicolumn{2}{c|}{ Siklus 2 } & \multirow{2}{*}{ Keterangan } \\
\cline { 2 - 5 } & Pre-test & Post-test & Pre-test & $\begin{array}{c}\text { Post- } \\
\text { test }\end{array}$ & \\
\hline Nilai Rata-rata & $59,30 \%$ & $68,26 \%$ & $71,78 \%$ & $82,69 \%$ & Meningkat \\
\hline Nilai Terendah & 49 & 52 & 58 & 62 & Meningkat \\
\hline Nilai Tertinggi & 75 & 89 & 84 & 99 & Meningkat \\
\hline Jumlah siswa tuntas & 8 & 15 & 17 & 19 & Meningkat \\
\hline $\begin{array}{l}\text { Persentase ketuntasan } \\
\text { klasikal }\end{array}$ & $34,78 \%$ & $65,21 \%$ & $73,91 \%$ & $82,60 \%$ & Meningkat \\
\hline
\end{tabular}

Gambaran peningkatan persiklus terlihat melalui grafik berikut:

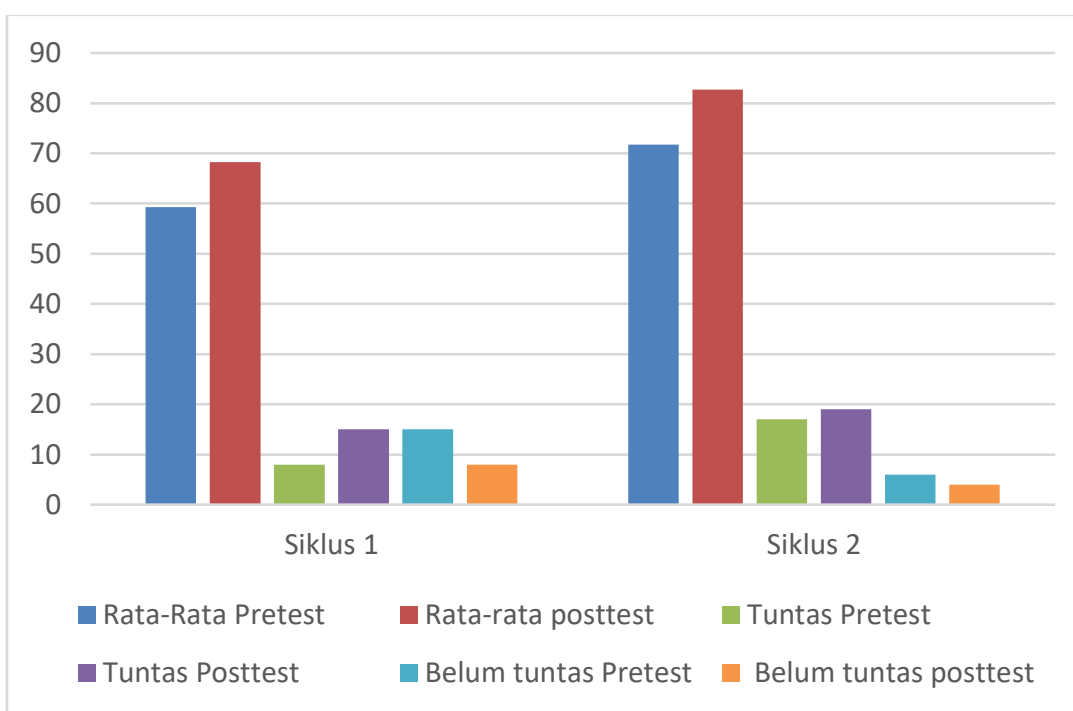


Gambar 6. Grafik Perbandingan Hasil Belajar Siklus 1 dan Siklus 2

Demikian juga data observasi yang terlihat melalui tabel berikut:

Tabel 7. Perbandingan Hasil Pengamatan Per aspek Siklus 1 dan Siklus 2

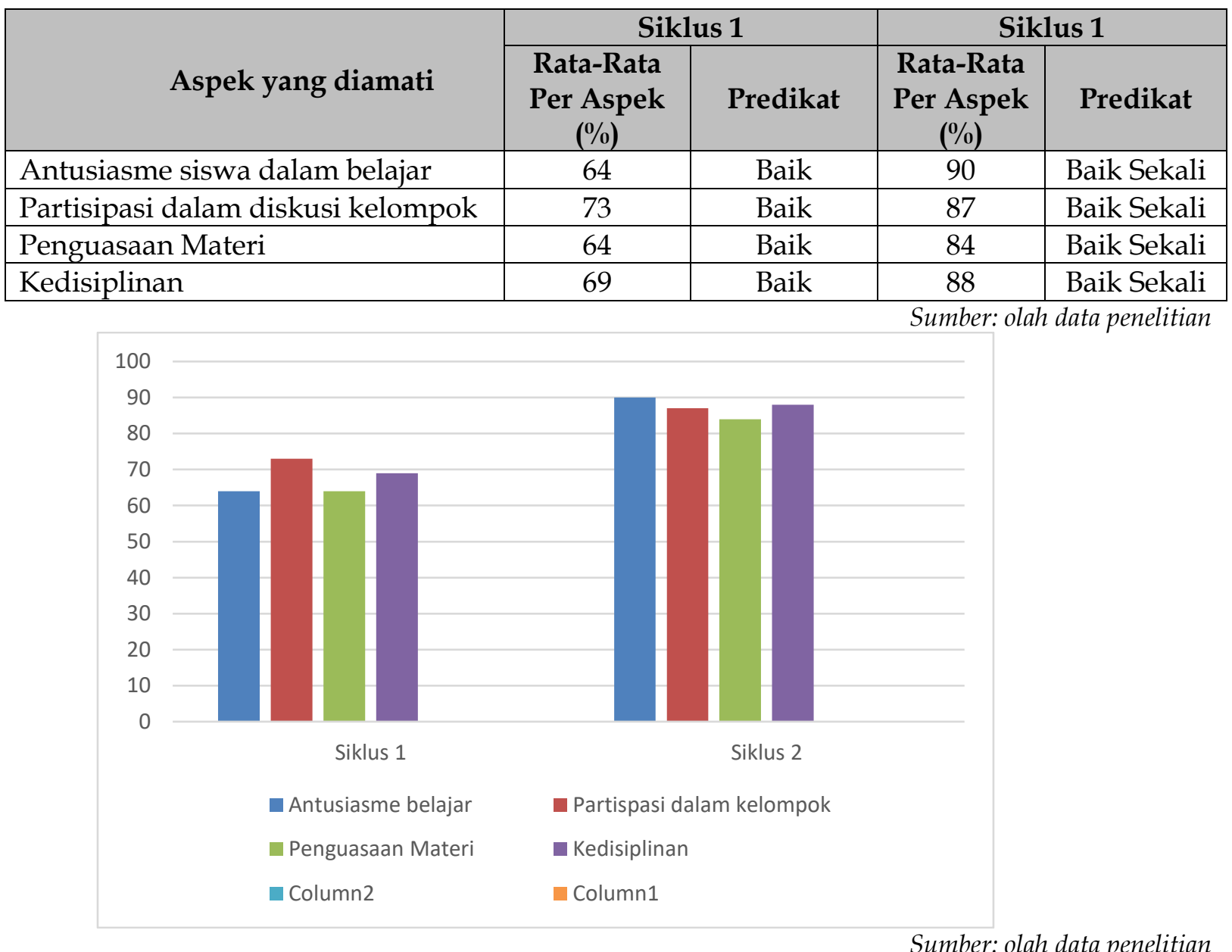

Gambar 7. Grafik Perbandingan Hasil Pengamatan Siklus 1 dan Siklus 2

Keberhasilan pembelajaran diprakarsai oleh adanya beberapa hal, yaitu: (1) perangkat pembelajaran yang disiapkan oleh peneliti dan guru sesuai dengan metode yang digunakan; (2) pada aspek antusias siswa dalam belajar dengan penerapan metode examples non examples sudah sangat baik hal ini di tunjukan dengan keseriusan siswa saat guru memulai pembelajaran dan melakukan apersepsi; (3) pada aspek diskusi dalam kelompok, semua siswa turut berpartisipasi dalam melakukan aktivitas kelompok; (4) pada aspek pemahaman materi, siswa sudah berani menyatakan pendapatnya ketika guru memberikan pertanyaan; (5) pada aspek kedisiplinan, siswa sudah tidak lagi tertawa atau mengolok teman ketika terjadi kesalahan pada presentasi hasil diskusi; (6) guru sudah mampu memaksimalkan penggunaan waktu pembelajaran; (7) guru sudah mampu melibatkan siswa dalam mengemukakan pendapat dengan baik; (8) guru sudah mampu memberikan penguatan kepada siswa dengan sikap yang terbuka, dan (9) umumnya suasana pembelajaran berjalan secara kondisif dan bersemangat. 


\section{Kesimpulan}

Penerapan metode pembelajaran examples non examples dalam mata pelajaran Pendidikan Agama Kristen terbukti efektif dapat meningkatkan hasil belajar kognitif siswa kelas VC SD Inpres Oesapa Kecil 1 Kota Kupang tahun ajaran 2018/2019. Hasil belajar dan keaktifan siswa mengalami peningkatan yang signifikan antara sebelum siklus dilaksanakan dengan setelah siklus terlaksana. Hal ini didukung oleh data penelitian baik data hasil belajar maupun data yang diperolah dari hasil pengamatan dan unjuk kerja.

Nilai rata-rata hasil belajar meningkat dari 59,30\% menjadi 82,69\%. Jumlah siswa yang mengalami ketuntasan belajar meningkat dari 34,78\% menjadi $82,60 \%$. Antusiasme siswa dalam belajar meningkat dari $64 \%$ menjadi $90 \%$. Partispasi dalam diskusi kelompok meningkat dari $73 \%$ menjadi $87 \%$. Penguasaan materi meningkat dari $64 \%$ menjadi $84 \%$, dan kedisiplinan siswa dalam melaksanakan pembelajaran mandiri dalam diskusi kelompok meningkat dari $69 \%$ menjadi $88 \%$. Dengan demikian peneliti menyimpulkan bahwa penerapan metode pembelajaran kooperatif tipe examples non examples pada siklus pertama dan kedua berhasil meningkatkan hasil belajar Pendidikan Agama Kristen pada ranah kognitif siswa kelas Vc SD Inpres Oesapa Kecil 1 Kota Kupang.

\section{Rekomendasi untuk Penelitian Lanjutan}

Peneliti menyadari bahwa metode pembelajaran kooperatif tipe examples non exemples bukanlah satu-satunya metode pembelajaran yang dapat digunakan sebagai pendorong bagi keberhasilan sebuah proses pembelajaran. Metode lainnya dapat digunakan, dengan mempertimbangkan aspek ketepatan dengan konteks permasalahan pembelajaran dan kemampuan peniliti dalam menerapkan metode tersebut. Peneliti meyakini bahwa sebagai salah satu tipe dari pembelajaran kooperatif, metode examples non examples dapat digunakan bersamaan dengan tipe lain yang sejenis dalam rangka mendorong keberhasilan pembelajaran yang lebih baik lagi. Oleh karena itu penelitian pada tingkat lanjut sangat disarankan.

\section{Rujukan}

Anderson, Lorin W., and David R. Krathwohl, eds. Kerangka Landasan Untuk Pembelajaran, Pengajaran, Dan Asesmen. Yogyakarta: Pustaka Pelajar, 2014.

Arikunto, Suharsimi. Penelitian Tindakan Kelas. Jakarta: Bumi Aksara, 2009.

Bujuri, Dian Andesta. "Analisis Perkembangan Kognitif Anak Usia Dasar Dan Implikasinya Dalam Kegiatan Belajar Mengajar." LITERASI IX, no. 1 (2018): 37-50.

Djamarah, Syaiful Bahri, and Aswan Zain. Strategi Belajar Mengajar. Jakarta: Rineka Cipta, 2010.

Gunawan, Imam, and Anggarini Retno Palupi. “Taksonomi Bloom - Revisi Ranah Kognitif: Kerangka Landasan Untuk Pembelajaran, Pengajaran, Dan Penilaian." Journal Premiere Educandum: Pendidikan Dasar dan Pembelajaran 2, no. 2 (2012): 98-117.

Habibah, Syarifah. "Penggunaan Model Pembelajaran Examples Non Examples Terhadap Ketuntasan Hasil Belajar Siswa Pada Materi Tokoh-Tokoh Pergerakan Nasional Kelas V SDN 70 Banda Aceh." Jurnal Pesona Dasar 3, no. 4 (2016): 54-64.

Huda, Miftahul. Model-Model Pengajaran Dan Pembelajaran. Yogyakarta: Pustaka Pelajar, 2013. Hutapea, Rinto Hasiholan. "Evaluasi Pembelajaran Pendidikan Agama Kristen Pada Kurikulum 2013." Jurnal Ilmiah Religiosity Entity Humanity (JIREH) 1, no. 1 (2019): 1830.

Lestiawan, Fendi, and Arif Bintoro Johan. "Penerapan Metode Pembelajaran Example NonExample Untuk Meningkatkan Keaktifan Dan Hasil Belajar Dasar-Dasar Pemesinan." Jurnal Taman Vokasi 6, no. 1 (2018): 98-106.

Madya, Suwarsih. Penelitian Tindakan: Teori Dan Praktik. Bandung: Alfabeta, 2011. 
Manuain, Leryani Mince Maria, Ferdinant Alexander, and Marsi Bombongan Rantesalu. "Pengaruh Model Pembelajaran Jigsaw Terhadap Peningkatan Hasil Belajar Sejarah Pendidikan Agama Kristen." Ciencias: Jurnal Penelitian dan Pengembangan Pendidikan 1, $\begin{array}{llllll}\text { no. } 1 \text { (2018): } 1 \text { 12. Accessed November 11, } & \text {.19 }\end{array}$ https://ejournal.upg45ntt.ac.id/ciencias/article/view/9.

Nugroho, Puspo. "Pandangan Kognitifisme Dan Aplikasinya Dalam Pembelajaran Pendidikan Agama Islam Anak Usia Dini." Jurnal ThufulLA: Jurnal Inovasi Pendidikan Guru Raudhatul Athfal 3, no. 2 (2015): 281-304.

Purwanto, Ngalim. Prinsip-Prinsip Dan Teknik Evaluasi Pengajaran. Bandung: PT Remaja Rosdakarya, 2012.

Santrock, John W. Perkembangan Anak. Jakarta: Erlangga, 2007.

Shoimin, Aris. 68 Model Pembelajaran Inovatif Dalam Kurikulum 2013. Yogyakarta: Ar-Ruzz, 2016.

Siswono, Tatang Yuli Eko. Mengajar Dan Meneliti (Panduan Penelitian Tindakan Kelas Untuk Guru Dan Calon Guru). Surabaya: Unesa University Press, 2008.

Sudjana, Nana. Penilaian Hasil Proses Belajar Mengajar. Bandung: PT Remaja Rosdakarya, 2011.

Suyanti, Putri, Nurdinah Hanifah, and Dede Tatang Sunarya. "Penerapan Model Pembelajaran Examples Non Examples Pada Materi Tokok-Tokoh Sejarah Untuk Meningkatkan Hasil Belajar Siswa Kelas V SDN Gunungsari." Jurnal Pena Ilmiah 2, no. 1 (2017): 2051-2060.

Suyatno. Menjelajah Pembelajaran Inovatif. Sidoarjo: Madmedia Buana Pustaka, 2009.

Trianto. Mendesain Model Pembelajaran Inovatif Progresif: Konsep, Landasan Dan Implementasinya Pada KTSP. Jakarta: Kencana, 2010. 